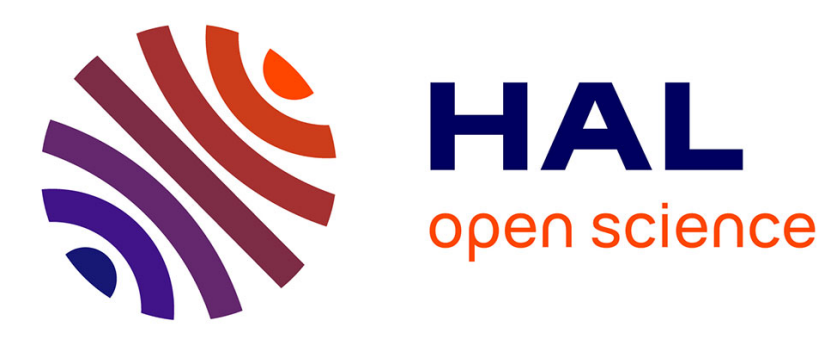

\title{
Does debt affect profitability? An empirical study of French trade sector \\ Mazen Kebewar
}

\section{To cite this version:}

Mazen Kebewar. Does debt affect profitability? An empirical study of French trade sector. 2013. halshs-00780310

\section{HAL Id: halshs-00780310 \\ https://shs.hal.science/halshs-00780310}

Preprint submitted on 23 Jan 2013

HAL is a multi-disciplinary open access archive for the deposit and dissemination of scientific research documents, whether they are published or not. The documents may come from teaching and research institutions in France or abroad, or from public or private research centers.
L'archive ouverte pluridisciplinaire HAL, est destinée au dépôt et à la diffusion de documents scientifiques de niveau recherche, publiés ou non, émanant des établissements d'enseignement et de recherche français ou étrangers, des laboratoires publics ou privés. 


\title{
Does debt affect profitability? An empirical study of French trade sector
}

\author{
Mazen KEBEWAR* \\ mazen.kebewar@gmail.com
}

\begin{abstract}
This article aims to expand existing empirical knowledge on the impact of debt level on profitability of companies. We analyze a sample of an unbalanced panel of 2325 unlisted French companies of trade sector spanning over a period of 1999 to 2006 . By using the generalized method of moments (GMM), we show that the debt affects negatively the profitability, not only linearly, but also, in a non-linear (concave) way. However, while analyzing according to different size classes (VSEs, SMEs and LEs); we find that the linear negative effect becomes larger and the non-linear effect is significant only in small and medium-sized enterprises (SME).
\end{abstract}

Keywords: Debt, GMM, Panel data, Profitability.

JEL Classification: C33, G32, L25.

* University of Orleans (France) - Faculty of Law, Economics and Management - Orleans Economic Laboratory (LEO), UMR CNRS 7322, Rue de Blois, B.P. 26739 - 45067 Orléans Cedex 2 - France.

* University of Aleppo (Syria) - Faculty of Economics - Department of Statistics and Management Information Systems, (مازن كبه وار ، جامعة حلب، كلية الاقتصاد - قسم الاحصاء ونظم المعلومات الادارية). 


\section{Introduction}

The role of debt in explaining firms' profitability is one of the primary concerns of several researches since the study of Modigliani and Miller (1958). However, this role remains a controversial subject which attracts the attention of many researchers as Goddard et al. (2005), Berger and Bonaccorsi (2006), Rao et al. (2007), Baum et al. (2006), Weill (2008), Nunes et al. (2009) and Margaritis and Psillaki (2010). Indeed, researchers analyze the debt ratio and try to determine whether an optimal debt ratio exists or not. Optimal debt ratio is generally defined as the one which minimizes the cost of capital for the company, while maximizing the value of company. In other words, the optimal debt ratio is the one which maximizes the profitability of company.

The divergence between researchers can be observed in theoretical strand of literature. There are three essential theories which highlight the influence of debt on corporate profitability, namely: signaling theory, the agency costs theory and tax theory. First, according to signaling theory, the debt; in the presence of asymmetric information, should be correlated positively to profitability. According to the agency costs theory, there are two contradictory effects of debt on profitability; firstly it is positive in the case of agency costs of equity between shareholders and managers, secondly it's effect is negative, resulting from the agency costs of debt between shareholders and lenders. Finally, the influence of taxation is complex and difficult to predict because it depends on the principles of; tax deductibility of interest on debt, income tax and nondebt tax shield.

In a similar vein, the disagreement also exists in empirical strand of related literature. A negative effect of debt on profitability was confirmed by Majumdar and Chhibber (1999), Eriotis et al. (2002), Goddard et al. (2005), Rao et al. (2007), Zeitun and Tian (2007) and Nunes et al. (2009). On the other hand, Baum et al. (2006), Berger and Bonaccorsi (2006), Margaritis and Psillaki (2007, 2010), showed a positive influence. In addition, Simerly and LI (2000), Mesquita and Lara (2003) and Weill (2008), find both effects in their studies. Besides that, Berger and Bonaccorsi (2006) and Margaritis and Psillaki (2007) finds the presence of a non linear effect (inverse U-shaped relationship). Finally, a non significant effect was confirmed by Baum et al. (2006) in American industrial companies.

Several factors may reveal reasons for the contradiction of results in empirical studies. First, these empirical studies focus on different types of sample (countries, sectors, companies and periods). Furthermore, researchers have used different measures of profitability as a dependent variable ${ }^{1}$ and various debt ratios as independent variable ${ }^{2}$. Finally, these studies applied different methodologies ${ }^{3}$.

The empirical literature concerning the impact of debt on profitability leads us to make two inferences. The first one is that most of the empirical studies focused on listed companies. The second one is related to paucity of studies on the French companies as we find only; Goddard et al. (2005), Weill (2008) and recently Margaritis and Psillaki (2010). These two avenues motivated our study. Moreover, current work is very important because debt is a risky choice

\footnotetext{
${ }^{1}$ ROA, ROE, ROI, PROF, Tobin's Q, Profit on sales, business performance, VRS: Technical Efficiency, CRS:

Technical Efficiency, Profit Margin, Frontier efficiency and BTI: ratio earnings before interest and tax to total assets.

${ }^{2}$ Ratio of total debt, ratio of short-term debt, and ratio of long-term debt.

${ }^{3}$ OLS, GLS, Weighted least squares, fixed effect, random effect, variance decomposition model, covariance model, maximum likelihood, Method of simultaneous equations, quantile regression and GMM.
} 
whose consequences on the corporate profitability can be considerable (e.g. the risk of bankruptcy and its consequences for the stakeholders). So we will try to find, empirically, the effect of debt on profitability for French unlisted trade companies. In addition, to improve the precision of estimation by reducing the heterogeneousness between sizes of companies, we study the behavior of these firms according to their size. Moreover, we will analyze not only the linear effect of debt on profitability, but also the non-linear effect by estimating a quadratic model which takes into account the squared of variable of debt in the equation of regression.

To do this, we will implement the generalized method of moments (GMM) estimation model on a sample of 2325 firms of trade sector observed over the period (1999-2006); these companies are divided into three 'size' classes: very small business (VSBs), small and medium enterprise (SMEs) and large enterprise (LEs). According to the proponents of GMM model, it provides solution to the problems of simultaneity bias, reverse causality bias (especially between profitability and debts) and the conundrum of possible omitted variables.

The structure of this paper is as follows. First, we discuss the characteristics of the sample and variables. Then, we present the empirical results. Finally, we wrap up the work with main findings and conclusions.

\section{Data}

\subsection{Data description}

Table (1) DESCRIPTIVE STATISTICS FOR VARIABLES

\begin{tabular}{|c|c|c|c|c|c|c|c|c|c|c|}
\hline & \multicolumn{4}{|c|}{ TOTAL } & \multicolumn{2}{|c|}{ VSES } & \multicolumn{2}{|c|}{ SMEs } & \multicolumn{2}{|c|}{ LEs } \\
\hline \multicolumn{2}{|c|}{ Number of companies } & \multicolumn{2}{|c|}{2325} & & \multicolumn{2}{|c|}{1639} & \multicolumn{2}{|c|}{655} & \multicolumn{2}{|c|}{31} \\
\hline \multicolumn{2}{|c|}{ Number of observations } & \multicolumn{2}{|c|}{13708} & & \multicolumn{2}{|c|}{9611} & \multicolumn{2}{|c|}{3915} & \multicolumn{2}{|c|}{182} \\
\hline & Mean & Std. Dev. & Min & $\operatorname{Max}$ & Mean & Std.Dev. & Mean & Std.Dev. & Mean & Std.Dev. \\
\hline$\overline{\mathrm{ROA}}$ & 0,058 & 0,059 & $-0,213$ & 0,320 & 0,059 & 0,063 & 0,055 & 0,050 & 0,056 & 0,034 \\
\hline PROF1 & 0,079 & 0,076 & $-0,163$ & 0,369 & 0,077 & 0,077 & 0,081 & 0,073 & 0,080 & 0,046 \\
\hline PROF2 & 0,085 & 0,077 & $-0,167$ & 0,408 & 0,083 & 0,077 & 0,092 & 0,077 & 0,085 & 0,042 \\
\hline DT & 0,629 & 0,174 & 0,118 & 0,973 & 0,621 & 0,176 & 0,648 & 0,168 & 0,657 & 0,138 \\
\hline GRTH & 0,050 & 0,171 & $-0,627$ & 2,798 & 0,046 & 0,177 & 0,059 & 0,155 & 0,087 & 0,620 \\
\hline TANG & 0,129 & 0,115 & 0,000 & 0,717 & 0,126 & 0,115 & 0,136 & 0,113 & 0,151 & 0,083 \\
\hline TAX & 0,197 & 0,141 & $-0,661$ & 0,829 & 0,175 & 0,141 & 0,246 & 0,128 & 0,279 & 0,080 \\
\hline
\end{tabular}

The sample consists of an unbalanced panel of 2325 French companies of trade sector, over the period of 1999-2006. Our sample is composed of unlisted companies like Limited Liability Companies and Limited Companies ${ }^{4}$. In addition, these companies belong to three classes of size (VSEs, SMEs and LEs) ${ }^{5}$. We apply several sample selection criteria to the original sample. Observations with the following characteristics are removed from the sample: (a) public enterprises because of their special political leverage; (b) companies with negative equity. In

\footnotetext{
${ }^{4}$ The composition of sample could be provided by requesting the author.

${ }^{5}$ According to the Classification of INSEE: very small enterprises (VSEs) which employs less than 20 employees, small and medium enterprises (SMEs) which employ between 20 and 249 employees, and finally (LEs) whose size is between 250 and 4999 employees.
} 
addition, we employ the procedure of Kremp $(1995)^{6}$ to reduce the potential impact of outliers upon the parameter estimates. Thus, table (1) presents descriptive statistics and the distribution of firms by size.

\subsection{Variables}

\subsubsection{Dependent variable}

In theory, profitability can be measured in different ways. In the context of our study and to compare our results, we use three measures of profitability: ROA, PROF1 and PROF2. (ROA) Return on Assets is measured by dividing net income from operations (to which income taxes are subtracted) by total capital. PROF1 is measured by dividing net income from operations by total assets. PROF2 is calculated by dividing earnings before interest and tax to total assets.

\subsubsection{Explanatory Variables}

Debt: According to the literature, debt ratio can be measured by several methods (i.e. total debt ratio, debt ratio as short, medium and long term). In our study, we define the total debt ratio (DT) by dividing the sum of the short and long-term debt by the total assets.

Growth opportunities: It is expected that firms with high growth opportunities have a high rate of return, because these companies are able to generate more profits from investment. So, growth opportunities should positively influence profitability. This positive impact is confirmed by Psillaki and Margaritis (2007), Zeitun and Tian (2007) and Nunes et al. (2009). On the other side, Margaritis and Psillaki (2010) find a negative effect only in the French chemical sector. Several measures to calculate growth opportunity for companies exists in literature. But in the context of our analysis, we use the ratio of growth opportunity (GRTH) which is measured by the change in total assets from one year to another.

Tangibility: Tangibility has two conflicting effects on profitability. On the one hand, we predict a negative correlation. Firms with high levels of tangible assets tend to be less profitable, because firms with high levels of intangible assets have more innovation, research and development and investment opportunities in the long term (Deloof 2003 and Nucci et al. 2005); the negative relationship between tangibility and profitability has been confirmed in number of studies as Rao et al. (2007), Zeitun and Tian (2007), Weill (2008) and Nunes et al. (2009). On the other hand, we expect a positive effect by Himmelberg et al. (1999); they show that tangible assets are easily monitored and provide good collateral and thus they tend to mitigate agency conflicts between shareholders and creditors; Majumdar and Chhibber (1999) and Margaritis and Psillaki (2007) find a positive relationship. To determine the effect of tangibility on profitability, we use the ratio (TANG); it is calculated by dividing the sum of net tangible assets to total assets.

$\underline{\text { Tax: }}$ : The tax impact on profitability of a company is difficult to predict, because it depends on the principle of tax deductibility of interest on debt. So, if a company does not take advantage of this principle, we expect a negative effect of tax on profitability. On the contrary, if a company takes advantage of this principle, this impact will be positive or not significant. Zeitun and Tian (2007) showed a positive effect of tax on profitability. The impact of tax on corporate profitability is highlighted by using the tax ratio in the regression equation. This ratio (TAX) is measured by total tax to earnings before interest and tax.

\footnotetext{
${ }^{6}$ We deleted the observations which are situated outside the interval defined by the first and third quartiles more or less five once the distance interquartile.
} 


\section{Methodology}

The empirical model in order to analyze the impact of debt on profitability is as follows:

$$
\operatorname{PROF}_{i, t}=\beta_{0}+\beta_{1} D T_{i, t}+\beta_{2} \text { RRTH }_{i, t}+\beta_{3} \text { TANG }_{i, t}+\beta_{4} T A X_{i, t}+\sum_{n=1}^{8} \beta_{n} d u m t_{n}+\eta_{i}+\varepsilon_{i t}
$$

Where, subscript ' $i$ ' denote the studied company and subscript ${ }^{6} t$ ' represent the time period. The dependent variable is the ratio of profitability (ROA, PROF1 or PROF2). Furthermore, (DT), (GRTH), (TANG) and (TAX) represent the ratios of debt, growth opportunities, tangibility and tax. Moreover, influence of time is taken into account by the introduction of annual dummies (dumt) that capture the specific year effect (1999-2006). The individual fixed effect on companies is represented by the term $\left(\eta_{i}\right)$. Finally, the error term which is assumed to be independent and identically distributed (iid) which is represented by the term $\left(\varepsilon_{i t}\right)$.

Regarding the effect of non-linearity between debt and profitability, we estimate a quadratic model which takes into account the debt variable squared in the regression equation. Thus, the model to estimate in this context is as follows:

$$
\operatorname{PROF}_{i, t}=\beta_{0}+\beta_{1} D T_{i, t}+\beta_{2} D T^{\wedge} 2_{i, t}+\beta_{3} G R T H_{i, t}+\beta_{4} T A N G_{i, t}+\beta_{5} T A X_{i, t}+\sum_{n=1}^{8} \beta_{n} d u m t_{n}+\eta_{i}+\varepsilon_{i t}
$$

The null hypothesis of linearity effect is to test $\left(\mathrm{H} 0: \beta_{2}=0\right)$. If this hypothesis is rejected, we can conclude the existence of non-linearity between debt and profitability. According to the agency cost theory, the effect of debt on profitability must be positive when $\left(\beta_{1}>0\right)$ and $\left(\beta_{1}+2 \beta_{2} D T_{i, t}>0\right)$. However, if the debt ratio arrives at an adequately high level, this effect can become negative. So, our quadratic specification is consistent with the possibility that the relationship between debt and profitability may not be monotonic, it may switch from positive to negative at a high level of debt. Debt will have a negative impact on profitability when $\left(D T_{i, t}<-\beta_{1} / 2 \beta_{2}\right.$ ). A sufficient condition for the inverse U-shaped relationship between debt and profitability to hold is that $\left(\beta_{2}<0\right)$.

We suspect problems of endogeneity in the estimation equation related to causality of exogenous variables to the dependent variable (especially the debt variable). Therefore, traditional econometric methods such as Ordinary Least Square, Fixed Effect and Generalized Least Square do not allow us to obtain efficient estimates of such model. So, to solve this problem, we introduce the generalized method of moments on panel (GMM) proposed by Arellano and Bond (1991), Arellano and Bover (1995) and Blundell and Bond (1998). This method can provide solutions to simultaneity bias, reverse causality and possible omitted variables. Indeed, GMM method is used to solve the problems of endogeneity not only at the debt variable, but also for other explanatory variables by using a series of instrumental variables generated by lagged variables. Moreover, it can control the individual and temporal specific effects. The model is estimated by two-step and one-step System GMM. In order to choose the best model specification, we examined several specifications according to different assumptions about the endogeneity of variables. 


\section{Results}

\subsection{Descriptive analysis}

The changes in profitability ratios are reported in Table (2). The profitability ratio for the sample, during the time period 1999-2006, is about 0.06 and 0.08 according to the ratio used. We note a decrease in profitability ratios between $-0.10 \%$ and $-0.17 \%$. Regarding the evolution of profitability according to the size, we note that the decrease in profitability concerns only to the very small enterprises (VSEs) and the small and medium enterprises (SMEs) whereas the large enterprises (LEs) have increased in profitability over the study period.

Table (2) CHANGES OF PROFITABILITY RATIO

\begin{tabular}{|c|c|c|c|c|c|c|c|c|c|c|c|c|}
\hline \multirow{2}{*}{$Y E A R$} & \multirow{2}{*}{ PROF1 } & \multirow{2}{*}{ PROF2 } & \multirow{2}{*}{$R O A$} & \multicolumn{3}{|c|}{ PROF1 } & \multicolumn{3}{|c|}{ PROF2 } & \multicolumn{3}{|c|}{$R O A$} \\
\hline & & & & VSEs & SMES & LEs & VSES & SMEs & LEs & VSEs & SMEs & LEs \\
\hline 1999 & 0,086 & 0,091 & 0,059 & 0,086 & 0,089 & 0,076 & 0,090 & 0,096 & 0,080 & 0,057 & 0,059 & 0,055 \\
\hline 2000 & 0,087 & 0,092 & 0,062 & 0,086 & 0,091 & 0,071 & 0,089 & 0,098 & 0,076 & 0,062 & 0,062 & 0,050 \\
\hline 2001 & 0,089 & 0,094 & 0,067 & 0,088 & 0,090 & 0,081 & 0,092 & 0,100 & 0,087 & 0,069 & 0,062 & 0,056 \\
\hline 2002 & 0,083 & 0,088 & 0,062 & 0,083 & 0,084 & 0,070 & 0,086 & 0,092 & 0,074 & 0,065 & 0,057 & 0,049 \\
\hline 2003 & 0,081 & 0,087 & 0,061 & 0,081 & 0,082 & 0,089 & 0,085 & 0,092 & 0,087 & 0,063 & 0,055 & 0,062 \\
\hline 2004 & 0,073 & 0,080 & 0,055 & 0,072 & 0,075 & 0,085 & 0,077 & 0,085 & 0,091 & 0,056 & 0,051 & 0,061 \\
\hline 2005 & 0,070 & 0,078 & 0,052 & 0,068 & 0,073 & 0,086 & 0,074 & 0,086 & 0,094 & 0,053 & 0,050 & 0,062 \\
\hline 2006 & 0,071 & 0,079 & 0,053 & 0,068 & 0,078 & 0,079 & 0,075 & 0,090 & 0,084 & 0,053 & 0,054 & 0,057 \\
\hline Average & 0,080 & 0,086 & 0,059 & 0,079 & 0,083 & 0,080 & 0,084 & 0,092 & 0,084 & 0,060 & 0,056 & 0,057 \\
\hline Change $\%$ & $-0,174$ & $-0,132$ & $-0,102$ & $-0,209$ & $-0,124$ & 0,039 & $-0,167$ & $-0,063$ & 0,050 & $-0,070$ & $-0,085$ & 0,036 \\
\hline
\end{tabular}

Note: (VSEs) less than 20 employees, (SMEs) between 20 and 249 employees, (LEs) between 250 and 4999 employees.

\subsection{Correlation between the variables}

Table (3) reports the correlation matrix for the variables. The results show that debt is negatively correlated with profitability. On the other hand, growth opportunities and tax have a positive correlation with profitability. Looking at the relationship between the independent variables themselves; the results of VIF test show that the multicollinearity is not a problem for the application of analytical techniques.

Table (3) PEARSON CORRELATION MATRIX

\begin{tabular}{lccccccc}
\hline & $P R O F 1$ & PROF2 & ROA & DT & GRTH & TANG & VIF \\
\hline PROF2 & $0.931 \ddagger$ & 1 & & & & & \\
ROA & $0.973 \ddagger$ & $0.867 \ddagger$ & 1 & & & & \\
DT & $-0.108 \ddagger$ & $-0.135 \ddagger$ & $-0.073 \ddagger$ & 1 & & & 1,03 \\
GRTH & $0.188 \ddagger$ & $0.171 \ddagger$ & $0.191 \ddagger$ & $0.068 \ddagger$ & 1 & & 1.02 \\
TANG & 0.009 & $0.017 \dagger$ & 0.001 & $0.085 \ddagger$ & $0.043 \ddagger$ & 1 & 1,01 \\
TAX & $0.388 \ddagger$ & $0.394 \ddagger$ & $0.284 \ddagger$ & $-0.109 \ddagger$ & $0.107 \ddagger$ & -0.013 & 1,03 \\
\hline
\end{tabular}

Note: $\downarrow, \dagger$ and $*$ represent statistical significance at the $1 \%, 5 \%$, and $10 \%$ levels, respectively. 


\subsection{Econometric analysis}

We estimated the effect of debt on profitability for 2325 French trade companies over the period between 1999 and 2006, by using various representatives of profitability ratio as (PROF1, PROF2 and ROA). Moreover, we used two different models (linear and nonlinear) to verify the presence of a non-linearity of this impact. Furthermore, our estimation focused specifically on studying the behavior of companies according to their size (VSEs, SMEs and LEs). So, the results of the estimation of GMM on panel data models with each of the profitability measures are displayed in Tables (4) and (5).

All our results are robust for the following reasons: First, we note that there is no 2nd-order autocorrelation of errors for difference equation, because the test of second order autocorrelation (AR2) does not allow rejecting the hypothesis of absence of second-order autocorrelation. Secondly, the instruments used in our regressions are valid, because Hansen test does not reject the hypothesis of validity of lagged variables in levels and in difference as instruments.

According to the linear model, it is observed that debt variable is negative and significant for all profitability ratios (between -0.116 and -0.168 ). So, this manifests that debt affect profitability negatively; an increase in the debt ratio of $1 \%$ causes a decrease of corporate profitability by almost $0.15 \%$. These findings support the results obtained by Majumdar and Chhibber (1999), Eriotis et al. (2002), Ngobo and Capiez (2004), Goddard et al. (2005), Rao et al. (2007), Zeitun and Tian (2007) and Nunes et al. (2009).

Regarding the impact of debt on profitability according to the quadratic model, we note that debt ratio squared $\left(\mathrm{D}^{\wedge} 2\right)$ variable is always negative and significant, implying that the null hypothesis of linearity is rejected. So, the significance of quadratic coefficient confirms the hypothesis of the existence of a non-linearity between debt and profitability. In addition, we report a concave relationship between debt and profitability as the coefficient of debt ratio squared $\left(\mathrm{D}^{\wedge} 2\right)$ is negative. Hence, this result converges with the agency theory and related findings obtained by Berger and Bonaccorsi (2006) and Margaritis and Psillaki (2007).

Furthermore, while analyzing the results of regression by size (Table 5), the linear impact of debt on profitability is always negative and significant in all size classes. In addition, this impact becomes larger (almost -0.25) in the second class (SMEs); this means that debt negatively affects the profitability of all trade enterprises, especially small and medium enterprises. Moreover, it is observed that there is a concave relationship between debt and profitability in all size classes, but this nonlinear nexus is significant only in the small and medium enterprises.

In a similar vein, regarding the control variables, we note; first, that the tangibility positively affects profitability only the small and medium enterprises, this means that these companies use their fixed assets efficiently. In addition, tax affects positively the profitability; it means that companies have high profitability level when they have increased taxes. On the other hand, growth opportunities negatively affect the profitability (between -0.069 and -0.115 ). 
Table (4) THE EFFECT OF DEBT ON PROFITABILITY

\begin{tabular}{|c|c|c|c|c|c|c|c|c|c|c|c|c|}
\hline \multirow[b]{3}{*}{ DT } & \multicolumn{6}{|c|}{ GMM : TWO STEPS } & \multicolumn{6}{|c|}{ GMM : ONE STEP } \\
\hline & \multicolumn{2}{|c|}{ PROF1 } & \multicolumn{2}{|c|}{ PROF 2} & \multicolumn{2}{|c|}{$R O A$} & \multicolumn{2}{|c|}{ PROF1 } & \multicolumn{2}{|c|}{ PROF2 } & \multicolumn{2}{|c|}{$R O A$} \\
\hline & $\begin{array}{c}-0,155 \ddagger \\
(-5,30)\end{array}$ & $\begin{array}{c}0,146^{*} \\
(1,67)\end{array}$ & $\begin{array}{c}-0,160+ \\
(-5,63)\end{array}$ & $\begin{array}{l}0,113 \\
(1,29)\end{array}$ & $\begin{array}{c}-0,116 \% \\
(-4,82)\end{array}$ & $\begin{array}{l}0,102 \\
(1,40)\end{array}$ & $\begin{array}{c}-0,162 \ddagger \\
(-5,55)\end{array}$ & $\begin{array}{l}0,140 \\
(1,58)\end{array}$ & $\begin{array}{c}-0,168 \div \\
(-5,82)\end{array}$ & $\begin{array}{l}0,098 \\
(1,09)\end{array}$ & $\begin{array}{c}-0,120 \$ \\
(-5,03)\end{array}$ & $\begin{array}{l}0,108 \\
(1,46)\end{array}$ \\
\hline $\mathrm{DT}^{* 2}$ & & $\begin{array}{c}-0,194 \dagger \\
(-2,56)\end{array}$ & & $\begin{array}{c}-0,186 \dagger \\
(-2,45)\end{array}$ & & $\begin{array}{c}-0,129 \dagger \\
(-2,04)\end{array}$ & & $\begin{array}{c}-0,201 \dagger \\
(-2,61)\end{array}$ & & $\begin{array}{c}-0,183 \dagger \\
(-2,38)\end{array}$ & & $\begin{array}{c}-0,143 \dagger \\
(-2,23)\end{array}$ \\
\hline GRTH & $\begin{array}{c}-0,089 \dagger \\
(-2,57)\end{array}$ & $\begin{array}{c}-0,093 \$ \\
(-2,63)\end{array}$ & $\begin{array}{c}-0,071 \dagger \\
(-1,96)\end{array}$ & $\begin{array}{c}-0,090 \dagger \\
(-2,17)\end{array}$ & $\begin{array}{c}-0,069 \dagger \\
(-2,32)\end{array}$ & $\begin{array}{c}-0,072 \dagger \\
(-2,44)\end{array}$ & $\begin{array}{c}-0,098 \dagger \\
(-2,31)\end{array}$ & $\begin{array}{c}-0,097 \dagger \\
(-2,42)\end{array}$ & $\begin{array}{c}-0,102 \dagger \\
(-2,30)\end{array}$ & $\begin{array}{c}-0,115 \neq \\
(-2,63)\end{array}$ & $\begin{array}{c}-0,073 \dagger \\
(-2,11)\end{array}$ & $\begin{array}{c}-0,069 \dagger \\
(-2,14)\end{array}$ \\
\hline TANG & $\begin{array}{l}0,011 \\
(1,08)\end{array}$ & $\begin{array}{c}-0,002 \\
(-0,21)\end{array}$ & $\begin{array}{l}0,016 \\
(1,56)\end{array}$ & $\begin{array}{l}0,006 \\
(0,60)\end{array}$ & $\begin{array}{l}0,006 \\
(0,68)\end{array}$ & $\begin{array}{l}-0,005 \\
(-0,57)\end{array}$ & $\begin{array}{l}0,012 \\
(1,21)\end{array}$ & $\begin{array}{l}0,003 \\
(0,35)\end{array}$ & $\begin{array}{c}0,020^{*} \\
(1,94)\end{array}$ & $\begin{array}{l}0,013 \\
(1,38)\end{array}$ & $\begin{array}{l}0,005 \\
(0,64)\end{array}$ & $\begin{array}{l}-0,003 \\
(-0,33)\end{array}$ \\
\hline TAX & $\begin{array}{l}0,179 \ddagger \\
(19,67)\end{array}$ & $\begin{array}{l}0,186 \% \\
(21,30)\end{array}$ & $\begin{array}{l}0,181 \ddagger \\
(19,55)\end{array}$ & $\begin{array}{l}0,186 \% \\
(20,01)\end{array}$ & $\begin{array}{l}0,109 \ddagger \\
(14,65)\end{array}$ & $\begin{array}{l}0,116 \ddagger \\
(16,58)\end{array}$ & $\begin{array}{c}0,180 \$ \\
(19,43)\end{array}$ & $\begin{array}{l}0,186 \ddagger \\
(21,12)\end{array}$ & $\begin{array}{l}0,185 \$ \\
(19,39)\end{array}$ & $\begin{array}{l}0,191 \ddagger \\
(20,60)\end{array}$ & $\begin{array}{l}0,110 \ddagger \\
(14,76)\end{array}$ & $\begin{array}{c}0,115 \ddagger \\
(16,48)\end{array}$ \\
\hline Constant & $\begin{array}{c}0,129 \ddagger \\
(7,36) \\
\end{array}$ & $\begin{array}{l}0,026 \\
(1,05) \\
\end{array}$ & $\begin{array}{r}0,138 \\
(8,14) \\
\end{array}$ & $\begin{array}{c}0,049 \dagger \\
(1,98) \\
\end{array}$ & $\begin{array}{r}0,100 \ddagger \\
(6,96) \\
\end{array}$ & $\begin{array}{l}0,021 \\
(1,04) \\
\end{array}$ & $\begin{array}{c}0,133 \$ \\
(7,61) \\
\end{array}$ & $\begin{array}{l}0,031 \\
(1,26) \\
\end{array}$ & $\begin{array}{r}0,143 \$ \\
(8,29) \\
\end{array}$ & $\begin{array}{r}0,056 \dagger \\
(2,26) \\
\end{array}$ & $\begin{array}{c}0,103 \ddagger \\
(7,18) \\
\end{array}$ & $\begin{array}{l}0,023 \\
(1,12) \\
\end{array}$ \\
\hline Observations & 11383 & 11383 & 11383 & 11383 & 11383 & 11383 & 11383 & 11383 & 11383 & 11383 & 11383 & 11383 \\
\hline Number of firm & 2325 & 2325 & 2325 & 2325 & 2325 & 2325 & 2325 & 2325 & 2325 & 2325 & 2325 & 2325 \\
\hline P- Sargan & 0,38 & 0,12 & 0,47 & 0,33 & 0,24 & 0,03 & 0,38 & 0,12 & 0,47 & 0,33 & 0,24 & 0,03 \\
\hline $\mathrm{P}-\mathrm{AR}(2)$ & 0,34 & 0,43 & 0,16 & 0,28 & 0,29 & 0,34 & 0,44 & 0,47 & 0,35 & 0,49 & 0,33 & 0,33 \\
\hline
\end{tabular}
Sargan-Hansen test of over-identifying restrictions (p-value reported). AR (2) is the test for 2nd order autocorrelation (p-value reported). Estimation by two-step and one step System GMM. Instruments: (DT) lagged $\mathrm{t}-2$ and $\mathrm{t}-3$, (DT*2) lagged $\mathrm{t}-2$, (GRTH) lagged $\mathrm{t}-2$, the rest of explanatory variables are exogenous.

Table (5) THE EFFECT OF DEBT ON PROFITABILITY BY SIZE CLASS

\begin{tabular}{|c|c|c|c|c|c|c|c|c|c|c|c|c|c|c|c|c|c|c|}
\hline \multirow[b]{3}{*}{ DT } & \multicolumn{6}{|c|}{ PROF1 } & \multicolumn{6}{|c|}{ PROF2 } & \multicolumn{6}{|c|}{$R O A$} \\
\hline & \multicolumn{2}{|c|}{ VSES } & \multicolumn{2}{|c|}{ SMES } & \multicolumn{2}{|c|}{ LEs } & \multicolumn{2}{|c|}{ VSES } & \multicolumn{2}{|c|}{ SMES } & \multicolumn{2}{|c|}{ LEs } & \multicolumn{2}{|c|}{ VSES } & \multicolumn{2}{|c|}{ SMES } & \multicolumn{2}{|c|}{ LEs } \\
\hline & $\begin{array}{c}-0,086 \dagger \\
(-2,46)\end{array}$ & $\begin{array}{l}0,106 \\
(1,10)\end{array}$ & $\begin{array}{c}-0,243 \$ \\
(-3,86)\end{array}$ & $\begin{array}{l}0,139 \\
(0,80)\end{array}$ & $\begin{array}{c}-0,160 \dagger \\
(-2,32)\end{array}$ & $\begin{array}{l}-0,058 \\
(-0,10)\end{array}$ & $\begin{array}{c}-0,099 \ddagger \\
(-3,00)\end{array}$ & $\begin{array}{l}0,097 \\
(1,03)\end{array}$ & $\begin{array}{c}-0,264 \dagger \\
(-4,05)\end{array}$ & $\begin{array}{l}0,112 \\
(0,62)\end{array}$ & $\begin{array}{c}-0,196 \% \\
(-3,40)\end{array}$ & $\begin{array}{l}-0,347 \\
(-0,79)\end{array}$ & $\begin{array}{c}-0,062 \dagger \\
(-2,04)\end{array}$ & $\begin{array}{l}0,064 \\
(0,78)\end{array}$ & $\begin{array}{c}-0,167 \ddagger \\
(-3,90)\end{array}$ & $\begin{array}{l}0,137 \\
(1,14)\end{array}$ & $\begin{array}{c}-0,107 \dagger \\
(-1,97)\end{array}$ & $\begin{array}{l}-0,074 \\
(-0,15)\end{array}$ \\
\hline $\mathrm{DT} * 2$ & & $\begin{array}{l}-0,119 \\
(-1,43)\end{array}$ & & $\begin{array}{c}-0,300^{*} \\
(-1,94)\end{array}$ & & $\begin{array}{l}-0,100 \\
(-0,20)\end{array}$ & & $\begin{array}{l}-0,127 \\
(-1,54)\end{array}$ & & $\begin{array}{c}-0,307 * \\
(-1,93)\end{array}$ & & $\begin{array}{l}0,132 \\
(0,37)\end{array}$ & & $\begin{array}{l}-0,067 \\
(-0,94)\end{array}$ & & $\begin{array}{c}-0,233 \dagger \\
(-2,16)\end{array}$ & & $\begin{array}{l}-0,027 \\
(-0,07)\end{array}$ \\
\hline GRTH & $\begin{array}{l}-0,092 \\
(-1,42)\end{array}$ & $\begin{array}{l}-0,085 \\
(-1,51)\end{array}$ & $\begin{array}{c}-0,059 \dagger \\
(-2,32)\end{array}$ & $\begin{array}{c}-0,053 \dagger \\
(-2,13)\end{array}$ & $\begin{array}{l}0,064 \\
(0,54)\end{array}$ & $\begin{array}{l}0,024 \\
(0,23)\end{array}$ & $\begin{array}{l}-0,093 \\
(-1,44)\end{array}$ & $\begin{array}{c}-0,113 * \\
(-1,92)\end{array}$ & $\begin{array}{l}-0,033 \\
(-1,34)\end{array}$ & $\begin{array}{l}-0,023 \\
(-0,83)\end{array}$ & $\begin{array}{l}0,033 \\
(0,35)\end{array}$ & $\begin{array}{l}0,050 \\
(0,81)\end{array}$ & $\begin{array}{l}-0,057 \\
(-1,06)\end{array}$ & $\begin{array}{l}-0,053 \\
(-1,11)\end{array}$ & $\begin{array}{c}-0,048 \dagger \\
(-2,17)\end{array}$ & $\begin{array}{c}-0,044 \dagger \\
(-2,17)\end{array}$ & $\begin{array}{l}0,071 \\
(0,81)\end{array}$ & $\begin{array}{l}0,023 \\
(0,31)\end{array}$ \\
\hline TANG & $\begin{array}{l}-0,008 \\
(-0,71)\end{array}$ & $\begin{array}{l}-0,018 \\
(-1,58)\end{array}$ & $\begin{array}{c}0,054 \dagger \\
(2,18)\end{array}$ & $\begin{array}{c}0,051 \dagger \\
(2,13)\end{array}$ & $\begin{array}{l}-0,006 \\
(-0,08)\end{array}$ & $\begin{array}{l}-0,023 \\
(-0,23)\end{array}$ & $\begin{array}{l}-0,003 \\
(-0,29)\end{array}$ & $\begin{array}{l}-0,010 \\
(-0,93)\end{array}$ & $\begin{array}{r}0,065 \$ \\
(2,64)\end{array}$ & $\begin{array}{c}0,068 \ddagger \\
(2,82)\end{array}$ & $\begin{array}{l}-0,081 \\
(-1,12)\end{array}$ & $\begin{array}{l}-0,090 \\
(-1,33)\end{array}$ & $\begin{array}{l}-0,009 \\
(-0,85)\end{array}$ & $\begin{array}{l}-0,016 \\
(-1,61)\end{array}$ & $\begin{array}{c}0,036 \dagger \\
(2,12)\end{array}$ & $\begin{array}{c}0,033^{*} \\
(1,93)\end{array}$ & $\begin{array}{l}0,004 \\
(0,09)\end{array}$ & $\begin{array}{l}0,000 \\
(0,00)\end{array}$ \\
\hline TAX & $\begin{array}{l}0,183 \dagger \\
(14,94)\end{array}$ & $\begin{array}{l}0,186 \ddagger \\
(16,69)\end{array}$ & $\begin{array}{c}0,164 \ddagger \\
(7,32)\end{array}$ & $\begin{array}{c}0,159 \dagger \\
(8,28)\end{array}$ & $\begin{array}{c}0,307 \dagger \\
(6,15)\end{array}$ & $\begin{array}{c}0,298 \div \\
(5,46)\end{array}$ & $\begin{array}{l}0,187 \dagger \\
(15,07)\end{array}$ & $\begin{array}{l}0,193 \$ \\
(16,43)\end{array}$ & $\begin{array}{r}0,150 \ddagger \\
(6,37)\end{array}$ & $\begin{array}{c}0,140 \ddagger \\
(6,59)\end{array}$ & $\begin{array}{c}0,146 \dagger \\
(2,52)\end{array}$ & $\begin{array}{c}0,129 \dagger \\
(2,55)\end{array}$ & $\begin{array}{l}0,118 \ddagger \\
(11,60)\end{array}$ & $\begin{array}{l}0,122 \ddagger \\
(13,23)\end{array}$ & $\begin{array}{c}0,092 \ddagger \\
(5,96)\end{array}$ & $\begin{array}{c}0,092 \ddagger \\
(6,86)\end{array}$ & $\begin{array}{r}0,215 \$ \\
(5,99)\end{array}$ & $\begin{array}{c}0,197 \$ \\
(4,86)\end{array}$ \\
\hline Constant & $\begin{array}{c}0,088 \div \\
(4,43)\end{array}$ & $\begin{array}{l}0,022 \\
(0,82)\end{array}$ & $\begin{array}{c}0,184 \hbar \\
(4,35)\end{array}$ & $\begin{array}{l}0,072 \\
(1,48)\end{array}$ & $\begin{array}{l}0,092 \\
(1,64)\end{array}$ & $\begin{array}{l}0,077 \\
(0,42)\end{array}$ & $\begin{array}{c}0,101 \$ \\
(5,35)\end{array}$ & $\begin{array}{l}0,036 \\
(1,39)\end{array}$ & $\begin{array}{c}0,209 \$ \\
(4,76)\end{array}$ & $\begin{array}{l}0,104 \dagger \\
(2,04)\end{array}$ & $\begin{array}{c}0,177 \ddagger \\
(3,54)\end{array}$ & $\begin{array}{c}0,219^{*} \\
(1,67)\end{array}$ & $\begin{array}{c}0,069 \ddagger \\
(3,95)\end{array}$ & $\begin{array}{l}0,021 \\
(0,92)\end{array}$ & $\begin{array}{c}0,131 \neq \\
(4,56)\end{array}$ & $\begin{array}{l}0,040 \\
(1,21)\end{array}$ & $\begin{array}{l}0,060 \\
(1,29)\end{array}$ & $\begin{array}{l}0,056 \\
(0,38) \\
\end{array}$ \\
\hline Observations & 7972 & 7972 & 3260 & 3260 & 151 & 151 & 7972 & 7972 & 3260 & 3260 & 151 & 151 & 7972 & 7972 & 3260 & 3260 & 151 & 151 \\
\hline Number of firm & 1639 & 1639 & 655 & 655 & 31 & 31 & 1639 & 1639 & 655 & 655 & 31 & 31 & 1639 & 1639 & 655 & 655 & 31 & 31 \\
\hline P- Sargan & 0,08 & 0,125 & 0,31 & 0,301 & 0,41 & 0,971 & 0,13 & 0,23 & 0,21 & 0,26 & 0,32 & 0,98 & 0,05 & 0,06 & 0,34 & 0,41 & 0,47 & 0,92 \\
\hline $\mathrm{P}-\mathrm{AR}(2)$ & 0,43 & 0,401 & 0,52 & 0,533 & 0,88 & 0,939 & 0,34 & 0,47 & 0,39 & 0,36 & 0,20 & 0,22 & 0,20 & 0,17 & 0,91 & 0,86 & 0,62 & 0,60 \\
\hline
\end{tabular}

Notes: $\downarrow, \dagger$ and $*$ represent statistical significance at the $1 \%, 5 \%$, and $10 \%$ levels, respectively. T-students are provided in parentheses. Each equation includes year dummy variables. Sargan statistic is a

Sargan-Hansen test of over-identifying restrictions (p-value reported). AR(2) is the test for 2nd order autocorrelation (p-value reported). Estimation by two-step System GMM. Instruments: (DT) lagged $\mathrm{t}-2$ and $\mathrm{t}-3,(\mathrm{DT} * 2)$ lagged $\mathrm{t}-2$, (GRTH) lagged $\mathrm{t}-2$, the rest of explanatory variables are exogenous. 


\section{Conclusion}

In this paper, we are interested in the effect of debt on profitability of French trade companies. In other words, this article expands the empirical literature regarding the influence of debt on profitability.

There are three essential theories which highlight the influence of debt on corporate profitability, namely: signaling theory, tax theory and the agency costs theory. Furthermore, the disagreement between researchers observed not only theoretically but also empirically.

Lack of studies on French firms and the concentration of studies on listed companies and industrial companies have motivated our study. To do this, we examined empirically the impact of debt on profitability by using the generalized method of moments (GMM) on an unbalanced panel of 2325 French companies of trade sector observed over the period 1999-2006. Our sample is composed of unlisted companies like Limited Companies and Limited Liability Companies. In addition, in order to improve the precision of the estimation by reducing heterogeneousness between different sizes of companies, we studied the behavior of these firms according to their size (VSEs, SMEs and LEs). Moreover, we analyzed not only the linear effect of debt on profitability, but also the non-linear effect by estimating a quadratic model which takes into account the squared of debt variable in the regression equation.

This study underlines the following results: First, according to the linear model, debt has a negative influence on profitability in all size classes of trade enterprises; but this influence becomes larger in small and medium enterprises (SMEs). Secondly, while analyzing the quadratic model, it is noticed that there is a concave relationship between debt and profitability in all size classes, but this nonlinearity is significant only in small and medium enterprises (SMEs); this finding converges with the agency theory and the results obtained by Berger and Bonaccorsi (2006) and Margaritis and Psillaki (2007).

For potential research, it would be interesting to take into account some reflections. First, it will be interesting to extend this analysis across different components of corporate debt (longterm and short-term); because, according to most of the studies, contradictory effects have been found. Secondly, we ideally would add new specific variables for companies and sectors, for example, the ownership structure of the corporate capital and the environment in which companies operate. Finally, considering the fact that the relationship between debt and profitability can be non-linear, we can deepen our analysis by using econometric methods that can evaluate the effects of non-linearity as threshold models.

\section{References}

Arellano, M. and O. Bover (1995) "Another Look at the Instrumental-Variable Estimation of Error-Components Models" Journal of Econometrics 68, 29-52.

Arellano, M. and S. Bond (1991) "Some Tests of Specification for Panel Data: Monte Carlo Evidence and an Application to Employment Equations" Review of Economic Studies 58, 277-297.

Baum, C.F. Schafer, D. and O. Talavera (2006) "The Effects of Short-Term Liabilities on Profitability: A Comparison of German and US Firms" Boston College Working Papers in Economics 636, Boston College Department of Economics. 
Berger, A. and Bonaccorsi, di Patti E. (2006) "Capital structure and firm performance: A new approach to testing agency theory and an application to the banking industry" Journal of Banking \& Finance 30, 1065-1102.

Blundell, R. and S. Bond (1998) "Initial conditions and moment restrictions in dynamic panel data models" Journal of Econometrics 87, 115-143.

Deloof, M. (2003) "Does working capital management affect profitability of Belgian firms" Journal of Business Finance and Accounting 30, 573-588.

Eriotis, N.P. Franguoli, Z. and Z.V. Neokosmides (2002) "Profit Margin and Capital Structure: An Empirical Relationship" The Journal of Applied Business Research 18, 85-89.

Goddard, J. Tavakoli, M. and J. Wilson (2005) "Determinants of profitability in European manufacturing and services: Evidence from a dynamic panel data" Applied Financial Economics 15, 1269-1282.

Himmelberg, C. Hubbard, G. and D. Palia (1999) "Understanding the determinants of managerial ownership and the link between ownership and performance" Journal of Financial Economics 53, 353-384.

Kremp, E. (1995) "Nettoyage des données dans le cas de fichiers de données individuelles" Économie et Prévision 119, 169-194.

Majumdar, S. and P. Chhibber (1999) "Capital structure and performance: Evidence from a transition economy on an aspect of corporate governance" Public Choice 98, 287-305.

Margaritis, D. and M. Psillaki (2010) "Capital structure, equity ownership and firm performance" Journal of Banking \& Finance 34, 621- 632.

Margaritis, D. and M. Psillaki (2007) "Capital Structure and Firm Efficiency" Journal of Business Finance \& Accounting 34, 1447-1469.

Mesquita, J.M.C. and J.E. Lara (2003) "Capital structure and profitability: the Brazilian case" Academy of Business and Administration Sciences Conference, Vancouver, July 11-13.

Modigliani, F. and M.H. Miller (1958) "The Cost of Capital, Corporate Finance, and the Theory of Investment" American Economic Review 48, 261-297.

Nucci, F. Pozzolo, A. and F. Schivardi (2005) "Is firm's productivity related to its financial structure? Evidence from microeconomic data" working paper. Italy: Banca d'Italia, Research Department.

Nunes, P.J.M. Serrasqueiro, Z.M. and T.N. Sequeira (2009) "Profitability in Portuguese service industries: a panel data approach" The Service Industries Journal 29, 693-707.

Rao, N.V. Al-Yahyaee, K.H.M. and L.A.M. Syed (2007) "Capital structure and financial performance: evidence from Oman" Indian Journal of Economics and Business 7, 1-14.

Simerly, R. and M. LI (2000) "Environmental dynamism, capital structure and performance: a theoretical integration and an empirical test" Strategic Management Journal 21, 31-49.

Weill, L. (2008) "Leverage and Corporate Performance: Does Institutional Environment Matter?" Small Business Economics 30, 251-265.

Zeitun, R. and G. Tian (2007) "Capital structure and corporate performance evidence from Jordan” Australasian Accounting Business \& Finance Journal 1, 40-53. 